\title{
PENGARUH PAJAK TANGGUHAN, PERENCANAAN PAJAK DAN ASSET PERUSAHAAN TERHADAP MANAJEMEN LABA PADA PERUSAHAAN KIMIA YANG TERDAFTAR DI BURSA EFEK INDONESIA TAHUN 2013-2017
}

\author{
Dhea Pranatania Puspitasari ${ }^{1}$ dan Sri Murdiati ${ }^{2}$ \\ ${ }^{1}$ Program Studi Akuntansi dan ${ }^{2}$ Program Studi Manajemen Perpajakan \\ Fakultas Ekonomi dan Bisnis Universitas Pancasakti
}

\begin{abstract}
Objectives to be achieved in this research are: 1). To know the effect of tax deferred, tax planning and corporate assets together to earnings management at chemical company, 2). To determine the effect of deferred tax on earnings management at chemical companies, 3). To know the effect of tax planning on earnings management at chemical company, 4). To know the influence of company's asset to earnings management at chemical company. Data collection method used in this research is dentasiasi. While the data analysis and hypothesis test used are classical assumption testing, multiple linear regression analysis, simultaneous significance test ( $F$ statistic test), significant test of individual parameter ( $t$ test statistic), and Coefficient of Determination. Based on the calculation result there is significant influence of tax deferred, tax planning and company asset collectively to earnings management at chemical company proven from result of test of significant test of simultan parameter (statistic test $F$ ) got probability sig value equal to 0,022 <0,05. There is no significant partial tax effect on profit management in chemical companies as evidenced by the result of testing the significance of individual parameters (statistical test t) of deferred tax on earnings management obtained probability sig value of 0.904>0.05. There is significant influence of tax planning partially to earnings management at chemical company proven from result of test of significant test of individual parameter (statistic test t) tax planning to earnings management got probability sig value equal to 0,013 <0,05. There is no significant influence of company asset partially to earnings management at chemical company proved from result of calculation of test of significant individual parameter (statistic test t) company asset to earnings management got probability sig value equal to 0,166 <0,05.
\end{abstract}

Keywords: Deferred Tax, Tax Planning, Company Assets, Profit Management

\section{PENDAHULUAN}

Latar Belakang Masalah

Dalam praktik bisnis, umumnya perusahaan mengidentikkan pembayaran pajak sebagai beban sehingga akan berusaha untuk meminimalkan beban tersebut guna mengoptimalkan laba. Beragam cara dilakukan agar pelaku bisnis dapat meminimalkan pajaknya, baik melalui cara yang sesuai dengan undang-undang (lawful), maupun dengan cara yang bertentangan dengan undang-undang (unlawful). Cara-cara yang sesuai dengan 
undang-undang dapat dilakukan dengan menerapkan prinsip pengelolaan pajak (Manajemen Pajak) secara tepat dan layak. Tujuan dari manajemen pajak dibagi menjadi dua, yaitu: menerapkan peraturanperaturan perpajakan secara benar dan usaha efisiensi untuk mencapai laba dan likuiditas yang seharusnya. Manajemen pajak sendiri terdiri dari fungsi perencanaan, pelaksanaan, dan pengendalian. Fungsi perencanaan pajak (tax planning) sendiri merupakan kunci penting dalam merencanakan strategi efisiensi biaya pada aspek pada perusahaan (Suandy, 2016:6).

Dalam melakukan perhitungan dan pembayaran pajak, perusahaan biasanya melakukan upaya-upaya agar beban yang ditimbulkan dari pajak dapat ditekan sekecil mungkin untuk memperoleh peningkatan laba bersih setelah pajak yang akan berdampak pada nilai perusahaan (firm value). Salah satu cara yang dilakukan oleh manajemen untuk mengurangi jumlah pajak yang dibayarkan oleh perusahaan dengan melakukan perencanaan pajak atau tax planning. Tax planning merupakan tindakan penstrukturan yang terkait dengan konsekuensi potensi pajak, yang penekanannya pada pengendalian setiap transaksi yang ada konsekuensi pajak dengan tujuan mengefisienkan jumlah pajak yang akan di transfer ke pemerintah (Lestari, 2014).

Salah satu upaya yang dilakukan manajemen untuk memperoleh laba dari adanya perubahan tarif pajak badan ini adalah dengan mengalokasikan laba tahun sebelum perubahan tarif pajak badan ke tahun sesudah perubahan tarif pajak, dengan kata lain memindahkan penghasilan bersih ke periode pajak yang tarifnya lebih rendah. Jika perusahaan memandang peristiwa penurunan tarif pajak sebagai kesempatan untuk meminimalkan pajak, maka perusahaan akan menunda pengakuan laba atau mempercepat pengakuan biaya pada tahun 2009 sehingga laba pada tahun 2009 menjadi lebih rendah. Melalui cara ini perusahaan akan mendapatkan keuntungan sebesar penurunan tarif pajak kali besarnya laba yang ditunda. Secara akuntansi hal ini dapat diterima karena menganut prinsip akrual basis (Santana dan Wirakusuma, 2016).

Ukuran perusahaan adalah tingkat identifikasi kecil atau besarnya perusahaan. Menurut Prasetya (2016) ukuran perusahaan dapat ditentukan berdasarkan jumlah tenaga kerja, kapitalisasi pasar, total penjualan, total nilai aktiva, dan sebagainya. Semakin besar kapitalisasi pasar menandakan semakin perusahaan diketahui oleh masyarakat, semakin besar penjualan menandakan perputaran uang semakin banyak, dan semakin besar aktiva menandakan modal yang ditanam semakin banyak.

Perusahaan yang berukuran besar memiliki basis pemegang kepentingan yang lebih luas, sehingga berbagai kebijakan perusahaan besar akan berdampak lebih besar terhadap kepentingan publik dibandingkan dengan perusahaan kecil. Bagi investor, kebijakan perusahaan akan berimplikasi terhadap prospek cash flow dimasa yang akan datang. Bagi regulator (pemerintah) akan berdampak terhadap besarnya pajak yang akan diterima, serta efektifitas peran pemberian perlindungan terhadap masyarakat secara umum (Muliati, 2011). Perusahaan beraset 
besar akan memiliki dorongan yang lebih besar untuk melakukan praktek manajemen laba disbandingkan dengan perusahaan kecil, karena memiliki biaya politik lebih besar, selain itu perusahaan besar memiliki aktivitas operasional yang lebih kompleks dibandingkan perusahaan kecil, sehingga dapat memungkinkan untuk melakukan praktek manajemen laba (Santana dan Wirakusuma, 2016).

Fenomena adanya praktik manajemen laba pernah terjadi di pasar modal Indonesia, khususnya pada emiten manufaktur di Bursa Efek Jakarta. Contoh kasus terjadi pada PT Kimia Farma Tbk. Berdasarkan hasil pemeriksaan Bapepam (Badan Pengawas Pasar Modal, 2004), diperoleh bukti bahwa terdapat kesalahan penyajian dalam laporan keuangan PT Kimia Farma Tbk., berupa kesalahan dalam penilaian persediaan barang jadi dan kesalahan pencatatan penjualan, dimana dampak kesalahan tersebut mengakibatkan overstated laba pada laba bersih untuk tahun yang berakhir 31 Desember 2001 sebesar Rp 32,7 miliar (Ruliana, 2016).

Fenomena lainnya terkait manajemen laba adalah kasus yang baru-baru ini terjadi adalah skandal akuntansi yang dilakukan Toshiba. Kasus ini bermula ketika Toshiba sendiri mulai menyelidiki praktik akuntansi di divisi energi. Menurut sebuah komite independen, perusahaan menggelembungkan laba usaha Toshiba sebesar $¥ 151,8$ milyar ( $\$$ 1,2 milyar) selama tujuh tahun. Kepala eksekutif Toshiba dan presiden Hisao Tanaka mengundurkan diri atas skandal akuntansi yang mengguncang perusahaan. Delapan anggota dewan, termasuk wakil ketua Norio Sasaki, juga telah mengundurkan diri dari jabatan mereka sebagai bagian dari perombakan besar manajemen perusahaan. Akibat skandal akuntansi yang mengguncang perusahaan, saham Toshiba telah turun sekitar 20\% sejak awal april ketika isu-isu akuntansi ini terungkap. Nilai pasar perusahaan hilang sekitar $¥ 1.673$ triliun (\$13,4 milyar) dan para analis memperkirakan saham Toshiba masih akan terus menurun. Toshiba yang merupakan salah satu merek elektronik paling dikenal di dunia serta memiliki reputasi yang bagus itu kini hancur berantakan akibat skandal akuntansi yang telah dilakukan perusahaan (Prasetya, 2016).

Beberapa penelitian terdahulu yang membahas mengenai pengaruh perencanaan pajak terhadap manajemen laba antara lain Sumomba (2012) menjelaskan bahwa beban pajak tangguhan dan perencanaan pajak tidak berpengaruh terhadap praktik manajemen laba, kemudian Wijaya dan Martani (2011) menjelaskan bahwa Perusahaan yang memperoleh laba (profit firm) melakukan praktik manajemen laba yang lebih besar dibandingkan perusahaan yang mengalami kerugian serta Aditama dan Purwaningsih (2013) menjelaskan bahwa perencanaan pajak ternyata tidak berpengaruh positif terhadap manajamen laba, sementara Santana (2016) menjelaskan bahwa perencanaan pajak berpengaruh positif terhadap praktek manajemen laba. Penelitian terdahulu tersebut memberikan hasil penelitian yang tidak konsisten sehingga peneliti tertarik untuk meneliti kembali, pada unit yang berbeda yaitu perusahaan Perdagangan Besar Yang Terdaftar di Bursa Efek Indonesia, maka peneliti 
melakukan penelitian dengan judul

"Pengaruh Pajak Tangguhan,

Perencanaan Pajak dan Asset

Perusahaan Terhadap manajemen

Laba Pada Perusahaan Kimia Yang

Terdaftar di Bursa Efek Indonesia

Tahun 2013-2017”.

Pertanyaan Penelitian

Berdasarkan latar belakang yang telah diuraikan, maka rumusan masalah dalam penelitian ini adalah:

Apakah terdapat pengaruh pajak tangguhan, perencanaan pajak dan asset perusahaan secara bersama-sama terhadap manajemen laba pada perusahaan kimia yang terdaftar di Bursa Efek Indonesia Tahun 20132017?

Apakah terdapat pengaruh pajak tangguhan terhadap manajemen laba pada perusahaan kimia yang terdaftar di Bursa Efek Indonesia Tahun 2013-2017?

Apakah terdapat pengaruh perencanaan pajak terhadap manajemen laba pada perusahaan kimia yang terdaftar di Bursa Efek Indonesia Tahun 20132017?

Apakah terdapat pengaruh asset perusahaan terhadap manajemen laba pada perusahaan kimia yang terdaftar di Bursa Efek Indonesia Tahun 2013-2017?

Tujuan Penelitian

Sesuai dengan latar belakang dan rumusan masalah, maka tujuan penelitian ini adalah:

Untuk mengetahui pengaruh pajak tangguhan, perencanaan pajak dan asset perusahaan secara bersama-sama terhadap manajemen laba pada perusahaan kimia yang terdaftar di Bursa
Efek Indonesia Tahun 20132017.

Untuk mengetahui pengaruh pajak tangguhan terhadap manajemen laba pada perusahaan kimia yang terdaftar di Bursa Efek Indonesia Tahun 20132017.

Untuk mengetahui pengaruh perencanaan pajak terhadap manajemen laba pada perusahaan kimia yang terdaftar di Bursa Efek Indonesia Tahun 20132017.

Untuk mengetahui pengaruh asset perusahaan terhadap manajemen laba pada perusahaan kimia yang terdaftar di Bursa Efek Indonesia Tahun 20132017.

\section{KERANGKA PEMIKIRAN DAN HIPOTESIS}

Kerangka Pemikiran

Kerangka Pemikiran Dalam Penelitian Ini Digambarkan Sebagai Berikut:

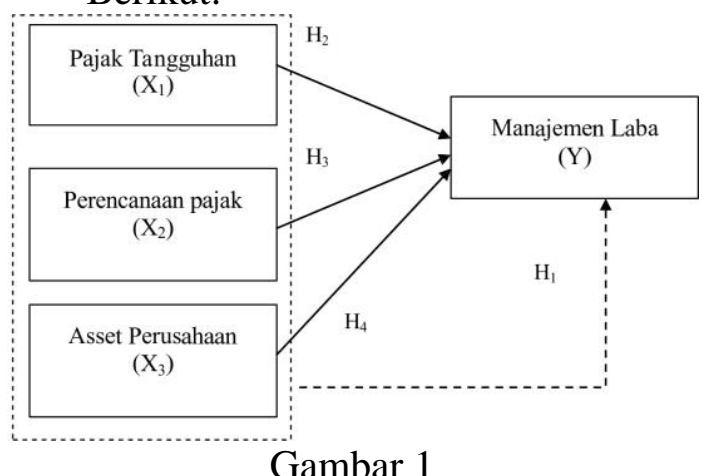

Kerangka Pemikiran

Hipotesis

Maka Hipotesis yang akan diuji dalam penelitian ini adalah:

Terdapat pengaruh pajak tangguhan, perencanaan pajak dan asset perusahaan secara bersamasama terhadap manajemen laba pada perusahaan kimia yang 
terdaftar di Bursa Efek Indonesia Tahun 2013-2017.

Terdapat pengaruh pajak tangguhan terhadap manajemen laba pada perusahaan kimia yang terdaftar di Bursa Efek Indonesia Tahun 2013-2017.

Terdapat pengaruh perencanaan pajak terhadap manajemen laba pada perusahaan kimia yang terdaftar di Bursa Efek Indonesia Tahun 2013-2017.

Terdapat pengaruh asset perusahaan terhadap manajemen laba pada perusahaan kimia yang terdaftar di Bursa Efek Indonesia Tahun 2013-2017.

\section{METODE PENELTIAN}

\section{Populasi Dan Sampel}

Population atau Universe adalah jumlah dari keseluruhan obyek (satuan-satuan/individuindividu) yang karakteristiknya hendak diduga (Djarwanto \& Subagyo, 2005: 107). Populasi dalam penelitian ini adalah seluruh perusahaan yang tergabung dalam perusahaan kimia yang terdaftar di Bursa Efek Indonesia Tahun 20132017 sejumlah 11 perusahaan.

Sampel adalah sebagian dari populasi yang karakteristiknya hendak diselidiki, dan dianggap bisa mewakili keseluruhan populasi (jumlahnya lebih sedikit daripada jumlah populasinya), (Djarwanto \& Subagyo, 2005: 108). Pengambilan sampel dilakukan dengan pertimbangan bahwa populasi yang ada sangat besar jumlahnya, sehingga tidak memungkinkan untuk meneliti seluruh populasi yang ada, sehingga dibentuk sebuah perwakilan populasi. Teknik pengambilan sampel dilakukan dengan menggunakan purposive sampling method. Perusahaan yang dipilih sebagai sampel dalam penelitian ini adalah perusahaan yang memiliki kriteria sebagai berikut:

Perusahaan yang tergabung dalam perusahaan kimia yang terdaftar di Bursa Efek Indonesia selama 5 tahun berturut-turut yaitu tahun 2013-2017.

Memiliki data yang lengkap terkait dengan variabel-variabel yang digunakan dalam penelitian.

Perusahaan tidak melakukan akuisisi, merger, restrukturisasi, serta perubahan kelompok usaha. Adanya akuisisi, merger, restrukturisasi, serta perubahan kelompok usaha tersebut akan menyebabkan laporan keuangan disajikan berbeda sehingga mempengaruhi posisi dan kinerja keuangan perusahaan.

Berikut ini akan dijelaskan tahapan dalam pengambilan sampel dalam penelitian ini yaitu:

Tabel 1 Tahapan Pengambilan Sampel

\begin{tabular}{|l|c|}
\hline \multicolumn{1}{|c|}{ Keterangan } & Jumlah \\
\hline $\begin{array}{l}\text { Total perusahaan kimia yang terdaftar di } \\
\text { Bursa Efek Indonesia }\end{array}$ & 11 \\
\hline $\begin{array}{l}\text { Perusahaan yang mengalami perubahan } \\
\text { kelompok usaha (pindah ke sektor lain) }\end{array}$ & $(0)$ \\
\hline Perusahaan yang mengalami delisting & $(0)$ \\
\hline $\begin{array}{l}\text { Perusahaan yang baru listing selama periode } \\
\text { pengamatan }\end{array}$ & $(3)$ \\
\hline Jumlah perusahaan sampel & 8 \\
\hline $\begin{array}{l}\text { Jumlah data observasi (8 perusahaan x 5 } \\
\text { tahun) }\end{array}$ & 40 \\
\hline
\end{tabular}

Definisi Konseptual dan Operasional Variabel

Definisi konseptual adalah adalah penarikan batasan yang menjelaskan suatu konsep secara singkat, jelas, dan tegas. Definisi 
konseptual dalam penelitian ini adalah:

Manajemen Laba (Y)

Manajemen laba adalah suatu tindakan yang terjadi ketika manajer menggunakan kebijakan dalam pelaporan keuangan dan dalam menyusun transaksi untuk mengubah laporan keuangan dan menyesatkan stakeholders mengenai kinerja ekonomi perusahaan, atau untuk mempengaruhi contractual outcomes yang tergantung pada angka akuntansi yang dilaporkan (Sulistyanto, 2009: 13).

\section{Pajak Tangguhan (X 1 )}

Beban pajak tangguhan dikelompokkan berdasarkan perbedaan temporer dan perbedaan permanen. pajak secara final, dan adanya non deductible expense (biaya yang tidak boleh dikurangkan) (Suandy, 2011:56).

Perencanaan Pajak (X 2)

Perencanaan pajak tindakan penstrukturan yang terkait dengan konsekuensi potensi pajaknya, yang tekanannya kepada pengendalian setiap transaksi yang ada konsekuensi pajaknya (Suandy, 2011:18).

\section{Asset perusahaan (X 3)}

Asset perusahaan pada dasarnya adalah semua hak yang dapat digunakan dalam operasi perusahaan (Dewi dan Ulupui, 2014:254). Operasional variabel merupakan proses penguraian variabel penelitian ke dalam subvariabel, dimensi, indikator sub variabel, dan pengukuran. Berikut ini akan dijelaskan operasional variable dalam penelitian ini:
Tabel 2

Definisi Konseptual DanOperasional

\begin{tabular}{|c|c|c|c|}
\hline Variabel & Definisi & Indikator & Pengukuran \\
\hline $\begin{array}{l}\text { Manajemen } \\
\text { Laba } \\
\text { (Y) }\end{array}$ & $\begin{array}{l}\text { Suatu tindakan yang } \\
\text { terjadi ketika manajer } \\
\text { mengubah laporan } \\
\text { keuangan dan } \\
\text { menyesatkan } \\
\text { stakeholders } \\
\text { mengenai kinerja } \\
\text { ekonomi perusahaan. }\end{array}$ & $\begin{array}{l}\text { Bila nilai } \Delta E \text { adalah nol } \\
\text { atau positif, maka } \\
\text { perusahaan menghindari } \\
\text { penurunan laba. } \\
\text { Bila nilai } \Delta E \text { adalah } \\
\text { negatif, maka perusahaan } \\
\text { menghindari pelaporan } \\
\text { kerugian } \\
\text { Rumus yang digunakan } \\
\text { adalah: } \\
\Delta E=\frac{E_{t t}-E_{t t-1}}{M V E_{t-1}}\end{array}$ & Rasio \\
\hline $\begin{array}{l}\text { Pajak } \\
\text { Tangguhan }\end{array}$ & $\begin{array}{l}\text { Beban pajak } \\
\text { tangguhan } \\
\text { dikelompokkan } \\
\text { berdasarkan } \\
\text { perbedaan temporer } \\
\text { dan perbedaan } \\
\text { permanen. pajak } \\
\text { secara final, dan } \\
\text { adanya non deductible } \\
\text { expense (biaya yang } \\
\text { tidak boleh } \\
\text { dikurangkan) }\end{array}$ & $\begin{array}{l}\text { Variabel beban pajak } \\
\text { tangguhan diukur diukur } \\
\text { dengan membagi jumlah } \\
\text { beban pajak tangguhan } \\
\text { dengan total aset } \\
\text { DTE }=\frac{\text { Deferred Tax Expense }}{\text { Total Assets }}\end{array}$ & Rasio \\
\hline $\begin{array}{l}\text { Perencanaan } \\
\text { pajak }\left(X_{1}\right)\end{array}$ & $\begin{array}{l}\text { Perencanaan pajak } \\
\text { tanpa melakukan } \\
\text { pelanggaran konstitusi } \\
\text { atau Udang-Undang } \\
\text { Perpajakan yang } \\
\text { berlaku }\end{array}$ & $\begin{array}{l}\text { Variabel perencanaan pajak } \\
\text { diukur dengan mengunakan } \\
\text { rumus tax retention rate } \\
\text { (tingkat retensi pajak), yang } \\
\text { menganalisis suatu ukuran } \\
\text { dari efektivitas manajemen } \\
\text { pajak pada laporan keuangan } \\
\text { perusahaan tahun berjalan. } \\
\text { Rumus yang digunakan } \\
\text { adalah: } \\
T R R=\frac{\text { Net Income it }}{\text { Pretax Income }(E B I T)_{i t}}\end{array}$ & Rasio \\
\hline $\begin{array}{l}\text { Aaset } \\
\text { perusahaan } \\
\left(\mathrm{X}_{3}\right)\end{array}$ & $\begin{array}{l}\text { Asset Perusahaan } \\
\text { dapat diartikan } \\
\text { sebagai suatu skala di } \\
\text { mana dapat } \\
\text { diklasifikasikan besar } \\
\text { kecil perusahaan } \\
\text { dengan berbagai cara } \\
\text { antara lain dinyatakan } \\
\text { dalam total aktiva, } \\
\text { nilai pasar saham, dan } \\
\text { lain-lain }\end{array}$ & $\begin{array}{l}\text { Logaritma natural total } \\
\text { aset/aktiva. Rumus yang } \\
\text { digunakan adalah: } \\
\text { Size = Log (Total Aktiva) }\end{array}$ & Rasio \\
\hline
\end{tabular}

Teknik Pengumpulan Data

Metode yang digunakan untuk mengumpulkan data dalam penelitian ini adalah metode dokumentasi. Metode dokumentasi menurut Arikunto (2010: 127) yaitu pengumpulan data yang dilakukan dengan mempelajari catatan-catatan atau dokumen perusahaan (data sekunder) serta studi pustaka dari berbagai literatur dan sumber-sumber lainnya yang berhubungan dengan masalah yang akan diteliti. Dalam penelitian ini masalah yang akan diteliti adalah perencanaan pajak dan manajemen laba. Data sekunder berisi tentang data-data annual report yang mencakup data perencanaan pajak dan manajemen laba serta rasio 
keuangan perusahaan manufaktur sektor kimia yang terdaftar di BEI untuk periode 2013-2017.

Analisis Data dan Uji Hipotesis

Metode analisis data yang digunakan adalah Uji asumsi klasik, analisis regresi linier berganda, uji signifikansi simultan (uji statistik f), uji signifikan parameter individual (uji statistik t), koefisien determinasi.

Pengujian Asumsi Klasik

Tujuan pengujian asumsi klasik ini adalah untuk memberikan kepastian bahwa persamaan regresi yang didapatkan memiliki ketepatan dalam estimasi, tidak bias dan konsisten. Suatu model regresi yang baik adalah model regresi yang memenuhi asumsi klasik yaitu, asumsi normalitas, multikolinieritas, autokorelasi dan heterokedastisitas.

Uji Normalitas

Uji normalitas bertujuan untuk menguji apakah dalam model regresi variabel terikat dan variabel bebas keduanya memiliki distribusi normal atau tidak. Model regresi yang baik adalah memiliki distribusi data normal atau mendekati normal. Model regresi yang memenuhi asumsi normalitas apabila data tersebut menyebar disekitar garis diagonal dan mengikuti arah garis diagonal (Ghozali, 2011:140).

Multikolonieritas

Uji Multikolinearitas bertujuan untuk menguji apakah pada model regresi ditemukan adanya korelasi antar variabel independen. Model regresi yang baik seharusnya tidak terjadi korelasi di antara variabel bebas. Jika variabel bebas saling berkorelasi, maka variabel-variabel ini tidak ortogonol. Variabel ortogonal adalah variabel bebas yang nilai korelasi antar sesama variabel bebas sama dengan nol (Ghozali, 2011).

Variabel yang menyebabkan multikolinearitas dapat dilihat dari nilai tolerance maupun VIF (Variance Inflation Factor). Model regresi yang bebas multikolinerietas mempunyai nilai VIF $<10$ dan mempunyai angka tolerance $>0,1$ atau mendekati 1 (Ghozali, 2011:140).

\section{Autokorelasi}

Autokorelasi muncul karena observasi yang berurutan sepanjang waktu berkaitan satu dengan yang lain. Masalah ini timbul karena residual tidak bebas dari satu observasi ke observasi lainnya. Dengan kata lain masalah ini seringkali ditemukan apabila kita menggunakan data runtut waktu. Untuk mendeteksi ada tidaknya autokorelasi digunakan uji Durbin Watson (DW Test). Untuk pengujian autokorelasi digunakan uji Durbin Watson hanya digunakan autokorelasi tingkat satu (first order autocorrelation) dan masyarakatkan adanya intercept (konstanta) independen. Pengambilan keputusan ada tidaknya autokorelasi: 
Tabel 3

\begin{tabular}{|l|l|l|}
\hline Hipotesis nol & Keputusan & Jika \\
\hline Tdk ada autokorelasi positif & Tolak & $0<\mathrm{d}<\mathrm{dl}$ \\
Tdk ada autokorelasi positif & No desicison & $\mathrm{dl} \leq \mathrm{d} \leq \mathrm{du}$ \\
Tdk ada autokorelasi negative & Tolak & $4-\mathrm{dl}<\mathrm{d}<4$ \\
Tdk ada autokorelasi negative & No decision & $4-\mathrm{du} \leq \mathrm{d} \leq 4-\mathrm{dl}$ \\
Tdk ada autokorelasi, & Tdk ditolak & $\mathrm{du}<\mathrm{d}<4-\mathrm{du}$ \\
Positif atau negatif & & \\
& & \\
& & \\
& & \\
\hline
\end{tabular}

Heteroskedastisitas

Uji heteroskedastisitas digunakan untuk menguji apakah dalam model regresi terjadi ketidaksamaan variance dan residual satu pengamatan ke pengamatan yang lain. Model regresi yang baik adalah yang tidak terjadi heteroskedastisitas. Ada atau tidaknya problem heteroskedastisitas pada model regresi dapat dideteksi dengan melihat ada atau tidaknya pola tertentu yang teratur pada grafik scatterplot serta titik-titik menyebar di atas dan di bawah angka 0 pada sumbu Y (Ghozali, 2011).

Analisis Regresi Linier Berganda Analisis regresi berganda digunakan untuk menguji pengaruh antara variabel bebas terhadap variabel terikat.

Persamaan regresi :

$\hat{\mathrm{Y}}=\mathrm{a}+\mathrm{b} 1 \mathrm{X} 1+\mathrm{b} 2 \mathrm{X} 2+\mathrm{b} 3 \mathrm{X} 3+$

$\mathrm{e}$

Keterangan :

$\hat{\mathrm{Y}}$ : Manajemen laba

a : Konstanta

b 1,2,3 : Koefisien regresi

$\mathrm{X} 1$ : Pajak tangguhan X2
Perencanaan pajak X3 :

Asset perusahaan

$\begin{array}{lr}\mathrm{e}=\begin{array}{l}\text { epsilon } \\ \text { pengganggu/ } \\ \text { error's) }\end{array} & \text { disturbance } \\ & \end{array}$

Uji Signifikansi Simultan (Uji

Statistik F)

Uji statistik $F$ pada dasarnya menunjukkan apakah semua variabel independen atau variabel bebas yang dimasukkan ke dalam model mempunyai pengaruh secara bersama-sama terhadap variabel dependen/terikat. Tingkat signifikasi atau probabilitasnya adalah sebesar 5\% atau 0,05. Dasar penerimaan atau penolakan hipotesis dilakukan dengan kriteria sebagai berikut (Ghozali, 2011: 99):

Jika nilai signifikan ${ }^{\rho}<0,05$ maka Ho ditolak yang artinya terdapat pengaruh yang signifikan antara variabel independen secara bersamasama terhadap variabel dependen.

Jika nilai signifikan ${ }^{\rho}>0,05$ maka Ho diterima yang artinya tidak artinya terdapat pengaruh yang signifikan antara variabel independen secara bersama-sama terhadap variabel dependen.

Uji Signifikan Parameter Individual (Uji Statistik t)

Uji statistik $t$ pada dasarnya menunjukkan seberapa jauh pengaruh satu variabel penjelas/independen secara individual dalam menerangkan variasi variabel dependen. Tingkat signifikasi atau probabilitasnya adalah sebesar $5 \%$ atau 0,05 . Dasar penerimaan atau penolakan hipotesis 
dilakukan dengan kriteria sebagai berikut (Ghozali, 2011: 99):

Jika nilai $\operatorname{signifikan}^{\rho}<0,05$ maka Ho ditolak yang artinya terdapat pengaruh yang signifikan antara satu variabel indpenden terhadap variabel dependen.

Jika nilai $\operatorname{signifikan}^{\rho}>0,05$ maka Ho diterima yang artinya tidak terdapat pengaruh yang signifikan antara satu variabel indpenden terhadap variabel dependen

\section{Koefisien Determinasi}

Dalam uji regresi linier berganda dianalisis pula besarnya koefisien determinasi $\left(\mathrm{r}^{2}\right)$ keseluruhan. $\mathrm{r}^{2}$ digunakan untuk mengukur ketepatan yang paling baik dari analisis regresi berganda. Jika $\mathrm{r}^{2}$ mendekati 1 (satu) maka dikatakan semakin kuat model tersebut dalam menerangkan variasi variable bebas terhadap variabel terikat. Sebaliknya jika $\mathrm{r}^{2}$ mendekati 0 (nol) maka semakin lemah variabel bebas menerangkan variabel terikat.

\section{HASIL ANALISIS DATA DAN UJI HIPOTESIS}

Pengujian Asumsi Klasik

Tujuan pengujian asumsi klasik ini adalah untuk memberikan kepastian bahwa persamaan regresi yang didapatkan memiliki ketepatan dalam estimasi, tidak bias dan konsisten. Suatu model regresi yang baik adalah model regresi yang memenuhi asumsi klasik yaitu, asumsi normalitas, multikolinieritas, autokorelasi dan heterokedastisitas.
Uji Normalitas

Uji normalitas bertujuan untuk menguji apakah dalam model regresi variabel terikat dan variabel bebas keduanya memiliki distribusi normal atau tidak. Model regresi yang baik adalah memiliki distribusi data normal atau mendekati normal. Model regresi yang memenuhi asumsi normalitas apabila data tersebut menyebar disekitar garis diagonal dan mengikuti arah garis diagonal (Ghozali, 2011:140).

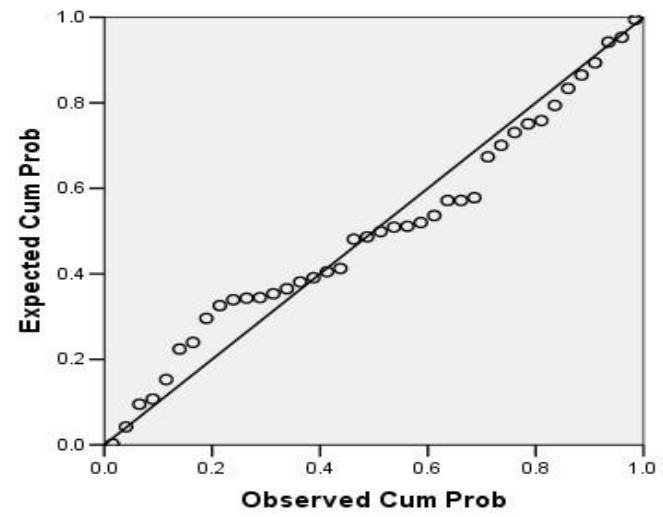

Gambar 2 Hasil Uji Normalitas Data

Berdasarkan hasil dari uji normalitas pada penelitian ini dapat dilihat bahwa titik-titik menyebar disekitar garis diagonal dan penyebaran mengikuti arah garis diagonal. Dengan demikian dapat dinyatakan bahwa penyebaran data mendekati normal atau memenuhi asumsi normalitas.

Dalam penelitian ini uji normalitas juga dilakukan dengan uji statistik, yaitu dengan analisis uji statistik non parametrik one sample kolmogorov smirnov. Ketentuan pengambilan keputusan pada uji one sample kolmogorov smirnov adalah bahwa jika probabilitas 
signifikansi di bawah 0,05 berarti data yang akan diuji mempunyai perbedaan yang signifikan dengan data normal baku, berarti data tersebut tidak normal. Sebaliknya jika signifikansi di atas 0,05 berarti data yang akan diuji mempunyai perbedaan yang signifikan dengan data normal baku, berarti data tersebut normal (Ghozali, 2011:140).

Tabel 4

One-Sample Kolmo gor ov-Smir nov

\section{Test}

\begin{tabular}{|ll|r|}
\hline & & $\begin{array}{r}\text { Unstandardiz } \\
\text { ed Residual }\end{array}$ \\
\hline $\mathrm{N}$ & & 40 \\
Normal Parameters $\mathrm{a}, \mathrm{b}$ & Mean &, 0000000 \\
& Std. Dev iation &, 14165328 \\
Most Extrem e $\quad$ Absolute &, 119 \\
Dif ferences & Positiv e &, 119 \\
& Negativ e & -119 \\
Kolmogorov -Smimov Z &, 753 \\
Asy mp. Sig. (2-tailed) &, 621 \\
\hline \multicolumn{2}{|c|}{ a. Test distribution is Normal. } \\
b. C Iculated from data.
\end{tabular}

a. Test distribution is Normal.

b. Calculated from data.

Berdasarkan hasil perhitungan diperoleh nilai signifikansi kolmogorov smirnov dengan unstandardized residual diperoleh nilai sebesar 0,621. Perbandingan antara probability dengan standar signifikansi yang sudah ditentukan diketahui bahwa nilai probability lebih besar dari 0,05. Sehingga menunjukkan bahwa distribusi data dalam penelitian ini normal.

\section{Multikolinieritas}

Uji Multikolinearitas bertujuan untuk menguji apakah pada model regresi ditemukan adanya korelasi antar variabel independen. Model regresi yang baik seharusnya tidak terjadi korelasi di antara variabel bebas. Jika variabel bebas saling berkorelasi, maka variabelvariabel ini tidak ortogonol. Variabel ortogonal adalah variabel bebas yang nilai korelasi antar sesama variabel bebas sama dengan nol (Ghozali, 2011).

Variabel yang menyebabkan multikolinearitas dapat dilihat dari nilai tolerance maupun VIF (Variance Inflation Factor). Model regresi yang bebas multikolinerietas mempunyai nilai VIF $<10$ dan mempunyai angka tolerance > 0,1 atau mendekati 1 (Ghozali, 2011:140).

Tabel 5

Hasil Uji Multikolinieritas

\section{Coefficienta ${ }^{\mathrm{a}}$}

\begin{tabular}{|l|r|r|}
\hline \multirow{2}{*}{ Model } & \multicolumn{2}{|c|}{ Collinearity } \\
\cline { 2 - 3 } & Tolerance & \multicolumn{1}{c|}{ VIF } \\
\hline 1 Pjk. Tangguhan &, 953 & 1,049 \\
Perencanaan Pjk. Aset &, 963 & 1,038 \\
Perusahaan &, 926 & 1,080 \\
& \\
\hline
\end{tabular}

a. Dependent Variable: Manajemen Laba

Dari hasil perhitungan uji asumnsi klasik pada bagian collinearity statistic terlihat untuk kedua variabel independen, angka VIF yaitu sebesar 1,$049 ; 1,038$ dan 1,080 yang lebih kecil dari 10 sehingga tidak melebihi batas nilai VIF yang diperkenankan yaitu maksimal sebesar 10. Dengan demikian dapat disimpulkan bahwa model regresi tersebut tidak terdapat masalah multikolinearitas.

Autokorelasi

Autokorelasi muncul karena observasi yang berurutan sepanjang waktu berkaitan satu dengan yang lain. Masalah ini timbul karena residual tidak bebas dari satu observasi ke 
observasi lainnya. Dengan kata lain masalah ini seringkali ditemukan apabila kita menggunakan data runtut waktu. Untuk mendeteksi ada tidaknya autokorelasi digunakan uji Durbin Watson (DWTest).

Heteroskedastisitas

Uji heteroskedastisitas digunakan untuk menguji apakah dalam model regresi terjadi ketidaksamaan variance dan residual satu pengamatan ke pengamatan yang lain. Model regresi yang baik adalah yang tidak terjadi heteroskedastisitas. Ada atau tidaknya problem heteroskedastisitas pada model regresi dapat dideteksi dengan melihat ada atau tidaknya pola tertentu yang teratur pada grafik scatterplot serta titik-titik menyebar di atas dan di bawah angka 0 pada sumbu Y (Ghozali, 2011).

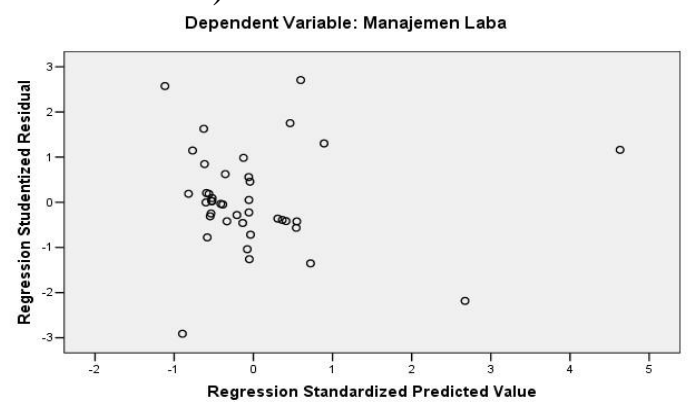

Gambar 3

Hasil Uji Heteroskedastisitas

Dari gambar di atas diketahui bahwa tidak ada pola tertentu yang teratur pada grafik scatterplot serta titik-titik menyebar di atas dan di bawah angka 0 pada sumbu Y. Dengan demikian dapat dikatakan bahwa data dalam penelitian ini tidak terjadi heteroskedastisitas.
Analisis Regresi Linier Berganda

Analisis regresi berganda digunakan untuk menguji pengaruh antara variabel bebas terhadap variabel terikat.

Tabel 7

Hasil Analisis Regresi Berganda

\begin{tabular}{|c|c|c|c|}
\hline \multirow[b]{2}{*}{ Model } & \multicolumn{2}{|c|}{$\begin{array}{l}\text { Unstandardized } \\
\text { Coefficients }\end{array}$} & $\begin{array}{l}\text { Standardized } \\
\text { Coefficients }\end{array}$ \\
\hline & B & Std. Error & Beta \\
\hline $\begin{array}{ll}\text { 1. } & \text { (Constant) } \\
\text { Pik. Jangguhan } \\
\text { Perencagaan Pik, } \\
\text { Aset Perusahaan }\end{array}$ & \begin{tabular}{r|}
,- 256 \\
.000 \\
.041 \\
.040
\end{tabular} & $\begin{array}{l}176 \\
002 \\
016 \\
028\end{array}$ & $\begin{array}{l}.018 \\
, 388 \\
215\end{array}$ \\
\hline
\end{tabular}

Berdasarkan hasil perhitungan, estimasi model regresi linier berganda antara pajak tangguhan, perencanaan pajak dan asset perusahaan terhadap manajemen laba diperoleh persamaan sebagai berikut:

$\hat{Y}=-0,256+0,000 X_{1}+0,041 X_{2}$ $+0,040 \mathrm{X}_{3}$

Dari model regresi dapat diartikan bahwa:

Nilai a (konstanta) sebesar 0,256 dapat diartikan bahwa jika tidak ada pajak tangguhan, perencanaan pajak dan asset perusahaan maka indeks manajemen laba akan bernilai sebesar $-0,256 \%$.

Koefisien regresi untuk pajak tangguhan sebesar 0,000 dan bertanda positif, menyatakan bahwa setiap peningkatan $1 \%$ pajak tangguhan maka akan meningkatkan manajemen laba sebesar $0,000 \%$.

Koefisien regresi untuk perencanaan pajak sebesar 0,041 dan bertanda positif, menyatakan bahwa setiap peningkatan $1 \%$ perencanaan pajak maka akan meningkatkan manajemen laba sebesar $0,041 \%$.

Koefisien regresi untuk aset perusahaan sebesar 0,040 dan 
bertanda negatif, menyatakan bahwa setiap peningkatan 1 juta ukuran perusahaan maka akan menurunkan manajemen laba sebesar $0,040 \%$.

Uji Signifikansi Simultan (Uji Statistik F)

Uji statistik $F$ pada dasarnya menunjukkan apakah semua variabel independen atau variabel bebas yang dimasukkan ke dalam model mempunyai pengaruh secara bersamasama terhadap variabel dependen/ terikat. Tingkat signifikasi atau probabilitasnya adalah sebesar 5\% atau 0,05. Dasar penerimaan atau penolakan hipotesis adalah jika nilai signifikan $^{\rho}<0,05$ maka hipotesis diterima yang artinya terdapat pengaruh yang signifikan antara variabel independen secara bersama-sama terhadap variabel dependen. Namun jika nilai signifikan $\rho>0,05$ maka hipotesis ditolak yang artinya tidak artinya terdapat pengaruh yang signifikan antara variabel independen secara bersama-sama terhadap variabel dependen.

Tabel 8

Hasil Uji Signifikan Simultan (Uji Statistik F)

\begin{tabular}{|c|c|c|}
\hline Model & $\mathrm{F}$ & Sig. \\
\hline $\begin{array}{ll}1 . & \text { Regression } \\
& \text { Residual } \\
& \text { Total }\end{array}$ & 3,605 &, $022^{a}$ \\
\hline
\end{tabular}

Dari hasil perhitungan di atas diketahui nilai signifikansi simultan sebesar $0,022<0,05$, artinya terdapat pengaruh yang signifikan pajak tangguhan, perencanaan pajak dan asset perusahaan secara bersama-sama terhadap manajemen laba pada perusahaan kimia yang terdaftar di Bursa Efek Indonesia Tahun 2013-2017.

Uji Signifikan Parameter Individual (Uji Statistik t)

Uji statistik t pada dasarnya menunjukkan seberapa jauh pengaruh satu variabel penjelas/ independen secara individual dalam menerangkan variasi variabel dependen. Tingkat signifikasi atau probabilitasnya adalah sebesar 5\% atau 0,05. Dasar penerimaan atau penolakan hipotesis dilakukan adalah jika nilai signifikan $\rho<$ 0,05 maka hipotesis diterima yang artinya terdapat pengaruh yang signifikan antara satu variabel indpenden terhadap variabel dependen.

Tabel 9

Hasil Uji Signifikan Parameter Individual (Uji Statistik t)

\begin{tabular}{|c|c|c|}
\hline Model & $t$ & Sig. \\
\hline $\begin{array}{ll}1 . & \text { (Constant) } \\
\text { Pjk, Jangguhan } \\
\text { Perencanaan Pjk, } \\
\text { Aset Perusahaan }\end{array}$ & $\begin{array}{r}-1,455 \\
, 121 \\
2,606 \\
1,413\end{array}$ & $\begin{array}{l}.154 \\
.904 \\
.013 \\
166\end{array}$ \\
\hline
\end{tabular}

Dari hasil perhitungan uji signifikan parameter individual (uji statistik t) pajak tangguhan terhadap manajemen laba didapat probabilitas nilai sig sebesar 0,904 $>0,05$ maka dapat diartikan bahwa tidak terdapat pengaruh yang signifikan pajak tangguhan secara parsial terhadap manajemen laba pada perusahaan kimia yang terdaftar di Bursa Efek Indonesia Tahun 20132017. Pajak tangguhan tidak berpengaruh signifikan terhadap terhadap manajemen laba karena perusahaan harus mengambil beberapa risiko akibat pengakuan beban pajak karena bagi perusahaan yang mengakui 
beban pajak tangguhan maka transaksi akan menggantung dan menumpuk. Pada tahun berikutnya ada pengakuan beban pajak tangguhan yang baru, maka akan semakin menumpuk. Hal ini akan mengurangi tingkat kepercayaan oleh pihak yang berkepentingan terhadap laporan keuangan yang disajikan terkait ketidak handalan laporan keuangan. Dalam penelitian ini data yang diolah pada beban pajak tangguhan tidak sepenuhnya terdiri dari beban pajak tangguhan. Terdapat aset pajak tangguhan dalam data diolah, sehingga menunjukkan yang tidak signifikan. Pada penelitian selanjutnya, untuk mengelolah data sebaiknya menggunakan semua beban pajak tangguhan untuk menguji langsung pengaruhnya terhadap manajemen laba.

Dari hasil perhitungan uji signifikan parameter individual (uji statistik t) perencanaan pajak terhadap manajemen laba didapat probabilitas nilai sig sebesar 0,013 $<0,05$ maka dapat diartikan bahwa terdapat pengaruh yang signifikan perencanaanan pajak secara parsial terhadap manajemen laba pada perusahaan kimia yang terdaftar di Bursa Efek Indonesia Tahun 2013-2017.

Dari hasil perhitungan uji signifikan parameter individual (uji statistik t) asset perusahaan terhadap manajemen laba didapat probabilitas nilai sig sebesar 0,166 $>$ 0,05 maka dapat diartikan bahwa tidak terdapat pengaruh yang signifikan aset perusahaan secara parsial terhadap manajemen laba pada perusahaan kimia yang terdaftar di Bursa
Efek Indonesia Tahun 20132017. Asset perusahaan tidak berpengaruh signifikan terhadap terhadap manajemen laba karena baik peruahaan dengan besar maupun perusahaan dengan asset kecil dalam penelitian ini mempunyai motivasi yang sama dalam melakukan manajemen laba. Beberapa perusahaan dengan aset besar mempunyai dorongan yang cukup besar untuk melaksanakan parktik manipulasi laba, alasan utamanya karena perusahaan yang berukuran besar harus dapat memenuhi ekspektasi yang tinggi dari pemegang saham atau investornya, sedangkan perusahaan dengan asset kecil melakukan manajemen laba agar mempunyai citra yang baik bagi para investor. Dalam menghitung ukuran perusahaan sebaiknya dapat menggunakan proksi lain seperti kepemilikan saham oleh publik, sehingga dapat dilihat pengaruhnya terhadap manajemen laba dalam peningkatan laba untuk kepentingan pemegang saham.

Koefisien Determinasi (R Square)

Dalam uji regresi linier berganda dianalisis pula besarnya koefisien determinasi $\left(\mathrm{r}^{2}\right)$ keseluruhan. $r^{2}$ digunakan untuk mengukur ketepatan yang paling baik dari analisis regresi berganda. Jika $\mathrm{r}^{2}$ mendekati 1 (satu) maka dikatakan semakin kuat model tersebut dalam menerangkan variasi variable bebas terhadap variabel terikat. Sebaliknya jika $\mathrm{r}^{2}$ mendekati 0 (nol) maka semakin lemah variabel bebas menerangkan variabel terikat. 
Tabel 10

Hasil Uji Koefisien Determinasi

\begin{tabular}{|l|r|r|r|r|}
\hline Model & R & R Square & $\begin{array}{l}\text { Adjusted } \\
\text { R Square }\end{array}$ & $\begin{array}{c}\text { Std. Error of } \\
\text { the Estimate }\end{array}$ \\
\hline 1 &, $481^{\text {g }}$ &, 231 &, 167 &, 14744 \\
\hline
\end{tabular}

Berdasarkan hasil perhitungan menggunakan program SPSS dapat diketahui nilai koefisien determinasi sebesar 0,231 . Nilai koefisien determinasi sebesar 0,231 tersebut mengandung arti bahwa pajak tangguhan, perencanaan pajak dan asset perusahaan secara bersama-sama memberikan pengaruh atau kontribusi kepada manajemen laba sebesar 23,1\% dan sisanya 76,9 \% dipengaruhi oleh faktor lain yang tidak dapat dijelaskan.

\section{KESIMPULAN DAN SARAN}

Kesimpulan

Berdasarkan hasil penelitian yang telah dilakukan maka dapat diambil beberapa kesimpulan sebagai berikut:

Terdapat pengaruh yang signifikan pajak tangguhan, perencanaan pajak dan asset perusahaan secara bersama-sama terhadap manajemen laba pada perusahaan kimia yang terdaftar di Bursa Efek Indonesia Tahun 2013-2017. Hal tersebut dapat dibuktikan dari hasil pengujian uji signifikan parameter simultan (uji statistik F) didapat probabilitas nilai sig sebesar $0,022<0,05$.

Tidak terdapat pengaruh yang signifikan pajak tangguhan secara parsial terhadap manajemen laba pada perusahaan kimia yang terdaftar di Bursa Efek Indonesia Tahun 2013-2017. Hal tersebut dapat dibuktikan dari hasil pengujian uji signifikan parameter individual (uji statistik t) pajak tangguhan terhadap manajemen laba didapat probabilitas nilai sig sebesar 0,904 >0,05.

Terdapat pengaruh yang signifikan perencanaanan pajak secara parsial terhadap manajemen laba pada perusahaan kimia yang terdaftar di Bursa Efek Indonesia Tahun 2013-2017. Hal tersebut dapat dibuktikan dari hasil pengujian uji signifikan parameter individual (uji statistik t) perencanaan pajak terhadap manajemen laba didapat probabilitas nilai sig sebesar 0,013 $<0,05$.

Tidak terdapat pengaruh yang signifikan aset perusahaan secara parsial terhadap manajemen laba pada perusahaan kimia yang terdaftar di Bursa Efek Indonesia Tahun 2013-2017. Hal tersebut dapat dibuktikan dari hasil perhitungan uji signifikan parameter individual (uji statistik t) asset perusahaan terhadap manajemen laba didapat probabilitas nilai sig sebesar 0,166 $<0,05$.

Saran

Berdasarkan kesimpulan dari penelitian ini, maka dapat diberikan beberapa saran sehubungan dengan penelitian ini, yaitu:

Pemerintah atau fiskus sebaiknya melakukan atau membuat peraturan yang ketat dari segi peraturan perpajakan, mengingat pajak merupakan pendapatan negara terbesar. Tentunya tujuan pembuatan peraturan yang ketat untuk mempersempit gerak perusahaan dalam melakukan manajemen laba dengan 
menurunkan jumlah laba perusahaan untuk menekan jumlah pajak yang dibayarkan.

Bagi perusahaan emiten baik perusahaan dengan ukuran yang besar atau kecil sebaiknya tidak melakukan manajemen laba, karena investor dan pemerintah memerlukan informasi yang sebenarnya dan tidak menyesatkan dalam mengambil kebijakan atau keputusan.

Penelitian selanjutnya diharapkan memasukan variabel lain yang dapat mempengaruhi manajemen laba, ataupun memasukan variabel intervening sehingga dapat mengetahui faktor apa yang dapat memperkuat atau memperlemah manajemen laba. Penelitian selanjutnya juga sebaiknya menambah periode penelitian.

Bagi penelitian terdahulu sebaiknya menggunakan proksi lain dalam mengukur variabel ukuran perusahaan misalnya menggunakan penjualan, menggunakan proksi lain dalam mengukur variabel manajemen laba misalnya dengan menggunakan dicretionary accruals.

\section{DAFTAR PUSTAKA}

Aditama, Ferry dan Anna Purwaningsih. 2013. "Pengaruh Perencanaan Pajak Terhadap Manajemen Laba Pada Perusahaan Non Manufaktur Yang Terdaftar di Bursa Efek Indonesia”. Jurnal Program Studi Akuntansi Fakultas Ekonomi Universitas Atma Jaya Yogyakarta. Online. www.e- journal.uajy.ac.id.

Arikunto, S. 2010. Prosedur penelitian : Suatu Pendekatan Praktik. (Edisi Revisi). Jakarta: Rineka Cipta. Dewi, Lindira Sukma dan I Gusti Ketut Agung Ulupui. 2014. "Pengaruh Pajak Penghasilan dan Asset Perusahaan terhadap Earning Management pada Perusahaan Manufaktur Terdaftar di BEI Tahun 20102012”. E-Jurnal Akuntansi Universitas Udayana 8.1 (2014): 250-259. Online. www.download.portalgaruda.org/article

Djarwanto PS, dan Subagyo, Pangestu. 2005. Statistik Induktif. Edisi Kelima. Yogyakarta: BPFE.

Ghozali, Imam. 2011. Aplikasi Analisis Multivariate dengan Program IBM SPSS 19. Semarang: Badan Penerbitan Universitas Diponegoro.

Lestari, Nanik. 2014. "Pengaruh Perencanaan Pajak Terhadap Nilai Perusahaan Dengan Moderasi Corporate Governance". SNA 17 Mataram, Lombok. Universitas Mataram 24-27 Sept 2014. Online. www.multi-paradigmalecture.ub.ac.id.

Muliati, Ketut. 2011. "Pengaruh Asimetri dan Ukuran Perusahaan Pada Praktek Manajemen Laba di Perusahaan Perbankan yang Terdaftar di BEI". Tesis. Universitas Udayana. Online. https://ojs.unud.ac.id/index.php/ Akuntansi. 
Prasetya, Pria Juni. 2016. "Pengaruh Ukuran Perusahaan Terhadap Manajemen Laba Dengan Pengungkapan Corporate Social Responsibility Sebagai Variabel Intervening. E-Jurnal Akuntansi Universitas Udayana Vol. 14.1 Januari 2016: 511-538. Online. https://ojs.unud.ac.id/index.php/ Akuntansi/article/view/17482

Ruliana, Ruly. 2016. "Pengaruh Earning Power Terhadap Earning Management". Akuntabilitas: Jurnal Ilmu Akuntansi. Volume 9 (1), April 2016 P-ISSN: 1979858X; E-ISSN: 2461-1190 Page 97 - 15

Suandy, Erly. 2016. Perencanaan Pajak. Jakarta: Salemba Empat

Sulistyanto, Sri. 2009. Manajemen Laba. Jakarta: Gramedia.

Wijaya, Maxson dan Dwi Martani. 2011. "Praktik Manajemen Laba Perusahaan Dalam Menanggapi Penurunan tarif Pajak Sesuai UU NO. 36 Tahun 2008" Simposium Nasional Akuntansi XIV Aceh $2011 \quad$ Universitas Syiah Kuala Banda Aceh 21-22 Juli 2011. Online. www.mfile.narotama.ac.id 